\title{
TRANSURETHRAL REMOVAL FOR SUCCESSFUL DIAGNOSIS OF BLADDER MALAKOPLAKIA: A RARE CASE REPORT
}

\author{
Ivo Vujichikj \\ University Clinic for Urology, University Clinical Centre "Mother Theresa", Skopje, \\ Republic of North Macedonia
}

Primljen/Received 08. 03. 2020. god.

Abstract: Introduction: Malakoplakia is a rare granulomatous inflammatory disorder of infectious etiology that most often involves the urinary tract. Because it is so rare and can present in several different ways, malakoplakia poses a difficult diagnostic challenge.

Case report: We report an unusual clinical case of bladder malakoplakia in a 75-year-old man. He presented to urologist with hematuria, burning on urination, urinary urgency and frequency. Cystoscopy evaluation revealed yellowish polypoid lesion with easy bleeding in the trigone of the bladder. Microscopic evaluation showed acidophilic, foamy histiocytes (Von Hansemann cells) admixed with Michaelis-Gutmann inclusions. The final postoperative diagnosis was malakoplakia of the bladder.

In conlusion, we reported a case of malakoplakia of the bladder diagnosed with minimally invasive approach by transurethral resection. It is important to be aware of this rare granulomatous disease as accurate diagnosis with antibiotic treatment can prevent possible complications.

Key words: Malakoplakia, Bladder, Transurethral resection.

\section{INTRODUCTION}

Malakoplakia is a rare granulomatous inflammatory disorder of infectious ethiology, that usually affects genitourinary system, mainly bladder in $60-80 \%$ of cases (1). The prevalence is unknown; however more than 700 cases have been studied so far (2). This rare disease should be considered in patients with recurrent coliform urinary infections, in immunocompromised patients and transplant recipients. It can be asymptomatic, or presents with painless hematuria, urinary tract infections, septicemia, acute renal failure or complica-
Prihvaćen/Accepted 13. 04. 2020. god.

tions of end stage renal failure (3). The pathophysiology of malakoplakia is uncertain, it is believed that it represents an unusual granulomatous response to bacterial infection (3). Clinically, as well as radiologically malakoplakia produces tumor-like lesions that are able to mimic malignant neoplasms, thus confirmation can only be achieved histologically.

The current report represents malakoplakia of bladder which presented histologically after a transurethral removal of bladder lesion. Malakoplakia represents a differential diagnosis which needs to be considered in these cases, since despite an appropriate early antibiotic long-term use; this type of infection might increase fast and significantly.

\section{CASE REPORT}

We report an unusual clinical case of bladder malakoplakia in a 75 year old man. He presented to urologist with a four-month history of hematuria, burning on urination, urinary urgency and frequency. Patient also had significant history of recurrent urinary tract infections (UTI) with Escherichia coli in the last nine months. His past medical history was positive for essential hypertension in the last four years, for which he was on atenolol. He denied any family history of genitourinary malignancy.

On admission, laboratory examinations (Table 1) were in the reference range. Urine analyses showed no signs of proteinuria but increase number of leukocytes and erythrocytes. Urine culture grew Escherichia coli, sensitive to quinolones. His blood pressure was 130/80 $\mathrm{mm} \mathrm{Hg}$, with a pulse rate of 74 beats/min. An initial ultrasound scan of the urinary tract showed presence of 2,5 $\mathrm{mm}$ tumor mass of the posterior bladder wall (Figure 1), without signs of ureteral obstruction. The contrast CT scan revealed hyperdense focus in the bladder 


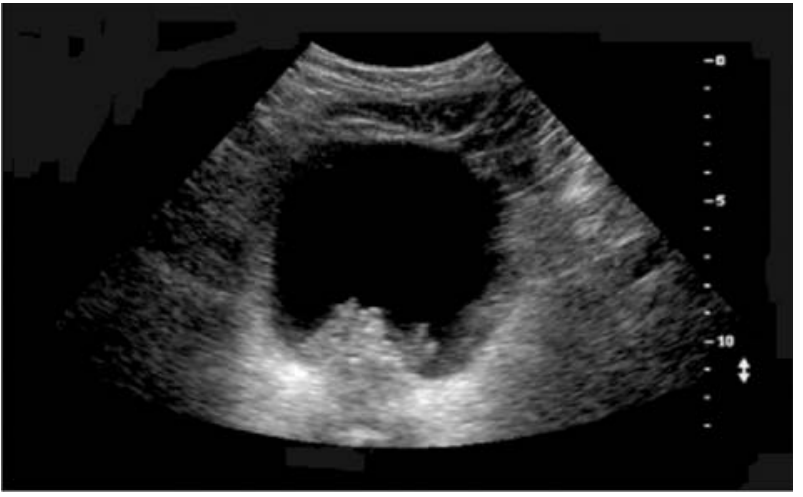

Figure 1. Ultrasound of the bladder shows mass of the posterior bladder wall

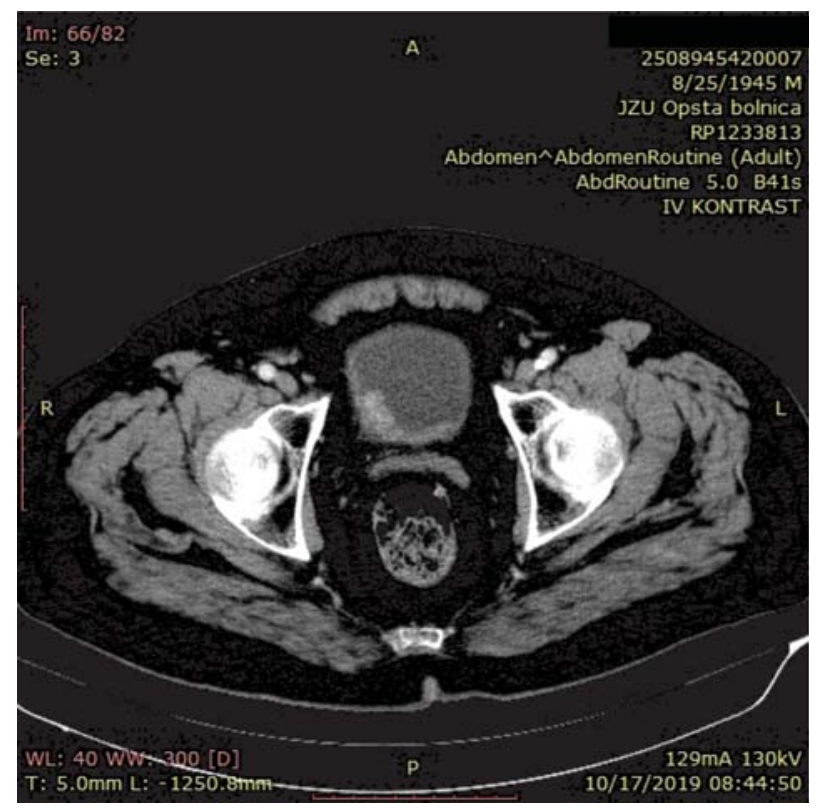

Figure 2. CT scan shows hyperdense focus of the bladder

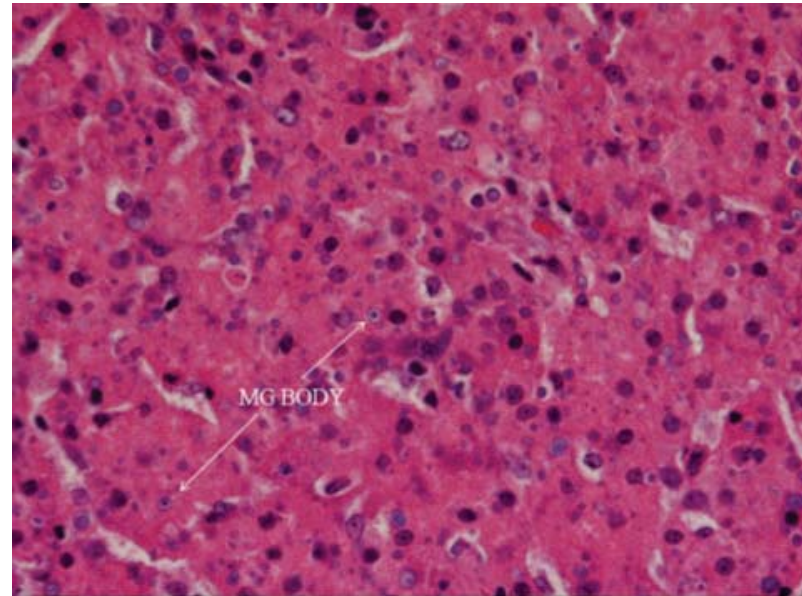

Figure 3. Foamy macrophages and Michaelis-Gutmann (MG) bodys. (H\&E stain magnification 400x)

measuring 2,5 x 1,5 mm (Figure 2). Cystoscopy evaluation revealed atypical yellowish polypoid lesion with easy bleeding in the trigone of the bladder. Malignancy was suspected and transurethral resection of the lesion was performed under spinal anesthesia. The patient was discharged home on first postoperative day with advice of antibiotic use with ciprofloxacin for 4 days and monthly follow-up.Microscopic evaluation showed acidophilic, foamy histiocytes (Von Hansemann cells) admixed with Michaelis-Gutmann inclusions (Figure 3). The final postoperative diagnosis was malakoplakia of the bladder.

\section{DISCUSSION}

Malakoplakia is benign and very rare chronic inflammatory granulomatous disease that mostly occurs

Table 1. Laboratory findings

\begin{tabular}{|l|c|c|}
\hline \multicolumn{1}{|c|}{ Test } & Result & Reference range \\
\hline WBC (white blood cells) $\times 10^{9} / \mathrm{L}$ & 6.4 & $4.00-9.00$ \\
\hline RBC (red blood cells) $\times 10^{12} / \mathrm{L}$ & 4.48 & $4.20-5.50$ \\
\hline Haemoglobin $\mathrm{g} / \mathrm{L}$ & 148 & $120-180$ \\
\hline Haematocrit (rv) & 0.460 & $0.37-0.54$ \\
\hline PLT (platelet count) $\times 10^{9} / 1$ & 261 & $150-450$ \\
\hline Glucose $(\mathrm{mmol} / \mathrm{l})$ & 5.07 & $3.5-6.5$ \\
\hline Urea $(\mathrm{mmol} / \mathrm{l})$ & 4.8 & $2.7-7.8$ \\
\hline Creatinine $(\mathrm{umol} / \mathrm{l})$ & 78 & $45-109$ \\
\hline Potassium $(\mathrm{mmol} / \mathrm{l})$ & 5.2 & $3.8-5.5$ \\
\hline Sodium $(\mathrm{mmol} / \mathrm{l})$ & 139 & $137-145$ \\
\hline Chlorides $(\mathrm{mmol} / \mathrm{l})$ & 106 & $99-108$ \\
\hline CRP $\mathrm{mg} / \mathrm{L}$ & 5 & $<6$ \\
\hline
\end{tabular}


in the genitourinary system. Malakoplakia mostly affects the bladder, prostate, ureter, kidney, female genital tract and retroperitoneal tissue (3). In general, malakoplakia of the urinary tract more frequently affects men above 50 years old (4). Cases of malakoplakia with involvement of the gastrointestinal tract and other visceral organ like lungs, bones, brain, conjunctiva, skin and tonsils has been described in the literature (5, $6,7)$.

Diagnosis of malakoplakia is still challenge because it presents clinically with wide spectrum of symptoms depending on organs involved. The symptoms of bladder malakoplakia, as in our case are hematuria, and signs of urinary tract infection, mimicking malignancy (2). Bladder malakoplakia has also been found in association with bladder tumors with or without a history of infection (8). Uretheral malakoplakia can manifest with uretheral obstruction and formation of structure. Renal malakoplakia may present with fever, flank pain and tumor-mass. Extensive pelvic malakoplakia has the potential to spread throughout the retroperitoneum and can cause renal failure if both ureters are compromised (9).

Bacterial infection and immunocompromised status are believed to be related to the development of malakoplakia. Escherichia coli is the most commonly isolated bacteria in urine culture in approximately $80 \%$ of cases (10). In addition to this microorganism, other possible factors are described, such are Klebsiella, Proteus, Mycobacterium, Staphylococcus and fungi (6). The pathophysiology of malakoplakia is uncertain, it included certain microorganism involvement such as gram-negative coliforms and defective phagocytosis in monocytes and macrophages (11). This results in accumulation of bacterial degradation products in monocytes and macrophages and developing granulomas. The bacterial degradation products persist in phagolysosomes and become mineralized; resulting in characteristic intracellular inclusions called Michaelis-Gutmann bodies (11). Intraluminal protrusion of bladder mucosa occurs due to accumulation of mac- rophages in the lamina propria (2), as in this case. Since this disease is rare and presents with hematuria, it is often misdiagnosed as malignancy.

Most bladder lesions may be detected by radiographic techniques (ultrasound, computed tomography and magnetic resonance). Contrast computed tomography is an important diagnostic investigation in upper urinary tract malakoplakia and can be presented with hydrourether and multiple hyperdense masses.

The diagnosis of malakoplakia is verified by biopsy and histopathological examination. The treatment consists of transurethral resection of the affected site and appropriate antibiotics according to result of antibiogram test from urine culture. The best antibiotics are those that achieve high intracellular antibiotics levels such as fluoroquinolones and thrimethoprim-sulfamethoxasol (12). Persistence of malakoplakia may require resection.

\section{CONCLUSION}

Inconclusion, we reported a case of malakoplakia of the bladder diagnosed with minimally invasive approach by transurethral resection. It is important to be aware of this rare granulomatous disease as accurate diagnosis with long term antibiotic treatment can prevent possible complications.

\section{Abbrevations \\ CT - computed tomography. \\ H\&E - hemathoxilin and eosin stain.}

Conflict of Interests: The authors declare that there are no conflicts of interest related to this article.

Funding: None

\section{Licensing}

This work is licensed under a Creative Commons Attribution 4.0 International (CC BY 4.0) License.

\title{
Sažetak
}

\section{TRANSURETRALNA RESEKCIJA MOKRAĆNE BEŠIKE ZBOG USPEŠNE DIJAGNOZE MALAKOPLAKIJE: PRIKAZ SLUČAJA}

\author{
Ivo Vujichikj \\ University Clinic for Urology, University Clinical Centre "Mother Theresa", Skopje, Republic of North Macedonia \\ Uvod: Malakoplakija je redak granulomatozni \\ inflamatorni poremećaj infektivne etiologije koji \\ najčešće obuhvata urinarni trakt. Obzirom da je ret- \\ ka bolest i može se manifestovati na više različitih \\ načina, malakoplakija predstavlja ozbiljan dijagno- \\ stički izazov. \\ Prikaz slučaja: Prikazujemo redak klinički slučaj \\ malakoplakije bešike kod 75-godišnjeg muškarca.
}


Upućen je kod urologa sa hematurijom, peckanjem pri mokrenju, urgentnom i učestalom mokrenju. Cistoskopski je detektovana žućkasta polipoidna lezija sa lakim krvarenjem na trigonumu bešike. Histopatološka evaluacija pokazala je acidofilne, penaste histiocite (Von Hansemann ćelije) pomešane sa MichaelisGutmann-ovim inkluzijama. Konačna postoperativna dijagnoza bila je malakoplakija bešike.

\section{REFERENCES}

1. Badillo LGF, Aguileria BI, Prada CS, Pedroza LVR, Lanzabal JDS. Renal malakoplakia. A case report. Rev Colomb Radiol. 2018; 29(3): 4987-91.

2. Kim SH, Choi YS, Kim ES, Lee K, Lee JH, Kang HG et al. Bladder malakoplakia mimicking bladder cancer. Korean J Med. 2017; 92(5): 476-9.

3. Dong H, Dawes S, Philip J, Caudhri S, Subramonian K. Malakoplakia of the urogenital tract. Urol Case Rep. 2014; 3(1): 6-8.

4. Wong SHL, Yeung VHW, Lee WK, Lee YK, Chan MTY, Cheng CH et al. Malakoplakia of the urinary tract: A benign disease with a possible malignant outcome. J Case Rep. 2016; 6: 254-8.

5. Niknejad N., Nili F., Shirkhoda M. Malakoplakia in association with adenocarcinoma of sygmoid colon: A case report. Iran J Pathol. 2019; 14(3): 258-60.

6. Kyriakou G, Gialeli E, Vryzaki E, Koumoundourou D, Glentis A, Georgiou S. Malakoplakia of the skin:overview of a rare clinical entity. Dermatol Online J. 2019; 25(6): 232-7.

7. Fudaba H, Ooba H, Abe T, Kamida T, Wakabayashi Y, Fujiki M, et al. An adult case of cerebral malakoplakia success-
Zaključak: Ukratko, prikazali smo slučaj malakoplakije bešike koja je dijagnostikovana transuretralnom resekcijom. Važno je da budemo svesni ove retke granulomatozne bolesti, jer tačna dijagnoza sa lečenjem antibioticima može sprečiti moguće komplikacije.

Ključne reči: Malakoplakia, Bešika, Transuretralna resekcija.

fully cured by treatment with antibiotics, bethanechol and ascorbic acid. J Neurol Sci. 2014; 342(1): 192-6.

8. Lee SL, Teo JK, Lim SK, Salkade HP, Mancer K. Coexistence of malakoplakia and papillary urothelial carcinoma of the urinary bladder. Int J Surg Pathol. 2015; 23(7): 575-8.

9. Patnayak R, Reddy MK, Subramanian S, Jena A, Ravisankar G, Dandu RS. An unusual case of bilateral hydroureteronephrosis caused by uretero-vesico malakoplakia in a young male: a case report and review of the literature. Cases J. 2009; 2(1): 7527.

10. Papilomata E, Agarwala N, Ioannnis M, Vorous MI, Balaxis AD, Filindris NT, Chalambous NS et al. Malakoplakia of genitourinary tract: A report of 3 cases. Urotoday Int J.2010; 3(4). Available from: http://dx.doi.org/10.3834/uij.1944-5784. 2010.08.12

11. Yousef GM, Naghibi B, Hamodat MM. Malakoplakia outside the urinary tract. Arch Pathol Lab Med. 2007; 131(2): 297-300.

12. Hina S, Hasan A, Iqbal N, Shabbir MU, Sheikh AAE. Malakoplakia of the urinary bladder and unilateral ureter. J Coll Physicians Surg Pak. 2019; 29 (6): 582-4.

\section{Correspondence to/Autor za korespondenciju}

Ivo Vujichikj

Majka Tereza 17, 1000 Skopje

Republic of North Macedonia

Tel. +38971269945

email: ivovujicic@yahoo.com 